\title{
KASATY OPACTW CYSTERSKICH NA POMORZU ZAODRZAŃSKIM W OKRESIE REFORMACJI
}

\section{Streszczenie}

Pomorze do okresu reformacji było krainą klasztorów i bogatego życia monastycznego, wszakże chrystianizacja regionu nastąpiła wyjątkowo późno, bowiem dopiero w XII wieku. Ze względu na pograniczne położenie i związaną z nim labilną sytuacją polityczną władcy sprowadzili ze Skandynawii oraz z głębi Cesarstwa Rzymskiego zakonników, którzy piastując funkcję duszpasterzy, przyczynili się do rozszerzenia wiary chrześcijańskiej na Pomorzu. W XII i XIII wieku zostały założone konwenty cysterskie, które do okresu reformacji prężnie rozwijały swą działalność, wpływając na życie publiczne oraz gospodarczo-polityczne.

Reformacja przebiegała na Pomorzu sukcesywnie i spokojnie, z wyjątkiem miasta hanzy Stralsund, gdzie wypędzono kleryków katolickich. Zwolennikami nauki Lutra szybko stali się młodzi alumni konwentów, w tym również zakonu cysterskiego, którzy pod wpływem humanizmu szerzonego na uniwersytetach byli otwarci na „nową naukę” reformatorów. Zmiana postawy młodych zakonników doprowadziła do wewnętrznego rozłamu zakonów, w związku z tym oficjalne przejęcie wyznania augsburskiego przez książęta pomorskie w 1534 roku, ustanawiające odejście Pomorza od katolicyzmu było logiczną konsekwencją stanu rzeczywistego wśród wiernych. Powyższa rozprawa przedstawia przebieg kasat dokonanych na klasztorach cysterskich na Pomorzu Zaodrzańskim. Głównym punktem odniesienia do dokumentacji źródłowych są zapiski sporządzone w przypadku klasztoru Eldena przez jednego z naocznych świadków zdarzeń - młodego zakonnika Antona Remmeldinga, a późniejszego pastora ewangelickiego. Mimo zabarwienia ideologicznego kronikarza przedstawiającego wcześniejsze wydarzenia już po przejściu na luteranizm, zapiski są ciekawym źródłem przedstawiającym dramaty między-

* Gregor Ploch - dr historii Kościoła; archidiecezja berlińska, OFE Haus St. Otto Zinnowitz; e-mail: gploch@aon.at

https://orcid.org/0000-0003-1753-8950 
ludzkie zakonników, którzy znaleźli się na ideologicznym froncie podziału między zagorzałymi obrońcami od stuleci przekazywanych wartości a radykalną nową nauką.

Słowa kluczowe: reformacja na Pomorzu; cystersi; kasata zakonów na Pomo$\mathrm{rzu}$; Jan Bugenhagen; Anton Remmelding; Erazm von Manteuffel; Eldena; Neuenkamp; Hiddensee; Stralsund; Greifswald; Białoboki; Trzebiatów; Kamień Pomorski; Gryfici; księstwo pomorskie

\section{Wstęp}

Pomorze cechuje specyficzna sytuacja wyznaniowo-polityczna pod względem przebiegu reformacji. W przeciwieństwie do innych regionów Cesarstwa Rzymskiego Narodu Niemieckiego czy sąsiadujących z nim księstw życie katolickie praktycznie kompletnie zniknęło w przeciągu paru dziesięcioleci od wygłoszenia przez Marcina Lutra słynnych 95 tez. W następstwie tego rozwoju wszystkie kościoły katolickie zostały przejęte przez wyznawców „,nowej nauki” (,neue Lehre") - jak przez długi czas niemieccy katolicy określali luteranów - część bogatszych klasztorów została przejęta przez regionalnych władców (książęta) i zaadaptowana na pałace czy siedziby administracji książęcych, resztę wyburzono, a materiał budowlany powtórnie wykorzystano na wzniesienie nowych obiektów mieszkalnych czy instytucji publicznych. Obiekty sakralne czy zasoby bibliotek klasztornych zostały rozproszone, a zbiory archiwalne klasztorów w większości zostały zniszczone. Ze względu na fakt, iż struktury Kościoła katolickiego - również na szczeblu diecezjalnym i parafialnym - zostały zeświecczone, nowo utworzony kościół ewangelicko-augsburski nie widział potrzeby przejęcia i przechowywania spuścizny materialnej po Kościele katolickim. Ochrona zabytków czy pojęcie „dziedzictwo kulturowe”, do którego zaliczamy dziś również zasoby archiwalne, to rozwój dziejów najnowszych zapoczątkowany dopiero w XIX wieku.

W związku z powyższym spuściznę materialną po skasowanych klasztorach na Pomorzu można obecnie podziwiać jedynie w sposób ograniczony. W zasobach archiwalnych byłych miast hanzy, jak Greifswald czy Stralsund, zachowały się wprawdzie poklasztorne akta archiwalne. Są to jednak fragmenty historii tych instytucji relacjonujące przeważnie stosunki prawno-handlowe $\mathrm{z}$ miastami czy władcą lub konflikty, które wyłoniły się na tym szczeblu. Tylko fragmentarycznie zachowała się dokumentacja archiwalna szerzej przedstawiająca przebieg przeprowadzenia kasat w poszczególnych klasztorach regulująca kwestie własnościowo-prawne wynikające $\mathrm{z}$ kasaty. Są to akta prawne zebrane w kancelarii książąt pomorskich dotyczące majętnych klasztorów posiadających włości ziemskie, m.in. zakony cystersów i norbertanów, książęta pomorscy bowiem osobiście przeprowadzali akt zeświecczenia tych wspólnot zakonnych, interesując się w głównej mierze ich majątkiem materialnym, o czym jeszcze będzie mowa. Część tych zbiorów znajduje się obecnie w zespole Archiwum Książąt Szczecińskich/Wołogoskich w zasobach Archiwum Państwowego w Szczecinie.

Praktycznie w ogóle nie zachowała się natomiast dokumentacja przedstawiająca sytuację panującą wewnątrz konwentów, która umożliwiłaby odtworzenie podziału międzyludzkiego w danym konwencie, idee Reformacji bowiem padły 
na podatny grunt również w szeregach zakonów. Klasztory odzwierciedlały spolaryzowaną sytuację społeczną, ponieważ i tam prowadzono wśród zwolenników i przeciwników nauk Lutra i Melanchtona zaciekłe dysputy teologiczne. Tylko w przypadku klasztoru Eldena zachowały się takie źródła - wspomnienia byłego zakonnika, o czym będzie mowa poniżej.

Podobną sytuację cechuje skromny stan badawczy dotyczący byłych klasztorów na Ziemi Zaodrzańskiej. Na przełomie XIX i XX wieku ukazały się jedynie dwie obszerniejsze pozycje, które do dzisiaj stanowią podstawową literaturę historyczną. W latach 1881-1883 greifswaldzki historyk (Karl) Theodor Pyl wydał trzytomowe dzieło przedstawiające historię opactwa cysterskiego Eldena ${ }^{1}$. Obszerniejszą tematycznie dwutomową edycję historii klasztorów pomorskich wydał w latach 1924-1925 emerytowany dyrektor Archiwum Państwowego w Szczecinie, Hermann Hoogeweg². Późniejsze nieliczne publikacje nawiązywały do tych dzieł i zajmowały się jedynie pojedynczymi zagadnieniami ${ }^{3}$. Kwestia kasat $\mathrm{w}$ okresie reformacji odgrywa w późniejszych publikacjach jednak marginalną rolę.

Zanim rozwiniemy zagadnienie, trzeba wyznaczyć interesujący nas historyczny region oraz jego nazewnictwo. Obecna północno-wschodnia część Niemiec i jednocześnie wschodnia część kraju związkowego Meklemburgia-Pomorze Przednie określana jest $\mathrm{w}$ teraźniejszej polskiej terminologii jako Pomorze Zaodrzańskie. Wybór nazewnictwa $\mathrm{w}$ obu językach pokazuje różną perspektywę spojrzenia. Dla Polaków jest to region Pomorza znajdujący się za Odrą, dla Niemców - odwrotnie: obszar krainy bałtyckiej leżący przed Odrą, dzielącej ten obszar od „właściwej” części Pomorza, z którą historiografia niemiecka (pruska) jest historycznie intensywniej związana. Jednak to nie Odra jest rzeką graniczną, a Reknica (Recknitz), dzieląca Meklemburgię od Pomorza (Przedniego). Meklemburgia od średniowiecza była księstwem przynależącym do Świętego Cesarstwa Rzymskiego z centrami w Rostocku i Schwerinie, które posiadały własną diecezję Schwerin (od XI wieku). Na terenie diecezji meklemburskiej działały dwa opactwa cysterskie - Doberan pod Rostokiem (1171) i Dargun (1172).

Natomiast Pomorze jako region pogranicza cechowała labilna sytuacja polityczna. Region znajdował się między Skandynawią, Świętym Cesarstwem Rzymskim a Koroną Polską. Północna część Pomorza - wyspa Rugia, zamieszkana

${ }^{1}$ T. Pyl, Geschichte des Cistertienserklosters Eldena im Zusammenhange mit der Stadt und Universität Greifswald, Bd/ 1, Greifswald 1880-1881.

${ }^{2}$ H. Hoogeweg, Die Stifter und Klöster der Provinz Pommern, Bd. 1, Szczecin 1924 oraz Bd. 2 , Szczecin 1925.

${ }^{3}$ A. Uckeley, Die letzten Jahre des Klosters Eldena, „Pommersche Jahrbücher“, 7 (1906) s. 27 87; H. Kloer, Das Zisterzienser-Kloster Eldena in Pommern (Kunstwissenschaftliche Studien, 1), Berlin 1929; A. Greifeld, Die Auswirkungen der mittelalterlichen Ostexpansion in Vorpommern und Rügen unter besonderer Berücksichtigung der Zisterzienserklöster Eldena und Neuenkamp, Diss. phil. (mps), Greifswald 1967; z najnowszych można wymienić: A. Niemeck, Die Zisterzienserklöster Neuenkamp und Hiddensee im Mittelalter (Veröffentlichungen der Historischen Kommission für Pommern V, 37), Köln u.a. 2002; Zisterziensische Klosterwirtschaft zwischen Ostsee und Erzgebirge. Studien zu Klöstern in Vorpommern, zu Himmelpfort in Brandenburg und Grünhain in Sachsen (Studien zur Geschichte, Kunst und Kultur der Zisterzienser, Bd. 19), Red. W. Schich, Berlin 2004. 
przez słowiański lud Ranów (Rugian), została podbita w 1168 roku przez duńskiego króla Waldemara I i tym samym jako jedna z ostatnich części kontynentu przyjęła chrześcijaństwo ${ }^{4}$. Nowo podbite ziemie funkcjonowały do 1325 roku jako księstwo rugijskie, będąc lennem królestwa duńskiego, i obejmowały teren Rugii oraz obszar lądowy sięgający od rzeki granicznej Reknicy na zachodzie poprzez miasto Stralsund do rzeki Ryck. Ta rzeka zaś dzieliła włości Rugian od terenu należącego do słowiańskiej dynastii Gryfitów, z którego powstało późniejsze księstwo pomorskie, podzielone (przez Odrę) na siedziby w Wołogoszczy (Wolgast) i Szczecinie. W 1325 roku księstwo rugijskie zostało wcielone do księstwa pomorskiego. Między 1325 a 1478 rokiem region zmieniał przynależność i należał do księstwa wołogosko-rugijskiego, księstwa wołogoskiego i księstwa pomorskiego.

Podbicie Rugii przez Duńczyków miało również następstwa w zakresie administracji kościelnej, wyspa bowiem do okresu reformacji należała do duńskiej diecezji Roskilde, natomiast część dawnego księstwa rugijskiego położona na lądzie aż do rzeki Ryck należała do meklemburskiej diecezji Schwerin. Teren panowania dynastii Gryfitów (na południe od rzeki Ryck) był związany zaś z diecezją kamieńską.

\section{Opactwa cysterskie na Pomorzu Zaodrzańskim}

Klasztory cysterskie położone między Łabą a Odrą wyróżniały się spośród opactw zachodnich swoistą specyfiką w zakresie miejsca fundacji oraz funkcji. Zakon lokował w tym regionie swoje dependencje wzdłuż głównych szlaków handlowych czy w pobliżu większych osad (częściowo posiadających już prawa miejskie), co niekoniecznie odpowiadało pierwotnej regule zakonu. Fakt ten ma jednak pewne uwarunkowanie. W przypadku Pomorza Zaodrzańskiego w chwili fundacji klasztorów - czyli na przełomie XII i XIII wieku - mamy do czynienia $\mathrm{z}$ regionem, w którym proces chrystianizacji nadal trwał, zatem cystersi przejmowali zadania duszpasterskie w licznych wsiach i osadach, wznosząc tam świątynie. Taka sama sytuacja panowała w Marchii Brandenburskiej.

Pierwszym opactwem cysterskim wzniesionym na Pomorzu Zaodrzańskim był klasztor Dargun, założony w 1172 roku przez duńskich cystersów z opactwa Esrum. Pierwotne położenie klasztoru w miejscowości Dargun znajdowało się jeszcze na terenie księstwa meklemburskiego, na pograniczu z księstwem rugijskim. Książę rugijski Jaromir I podarował duńskim cystersom solnisko położone ok. $50 \mathrm{~km}$ na północny wschód od Dargun przy ujściu rzeki Hilda ${ }^{5}$ do zatoki bałtyckiej o nazwie „Dänische Wiek” (obecnie: Zatoka Greifswaldzka). W dokumencie z 1193 roku mowa jest o „locum sartaginum in possessione, quae Hilda dicitur”.

${ }^{4}$ D. Bulach, Die städtischen Beziehungen der vorpommerschen Klöster Eldena, Neuenkamp und Hiddensee, w: Zisterziensische Klosterwirtschaft, s. 32-38.

${ }^{5} \mathrm{~W}$ kolejnych dziesięcioleciach pod wpływem osiadłych tam Słowian nadbałtyckich (Wendów) nazwę rzeki zmieniono na Ryck (od słowiańskiego słowa „reka”), którą nosi do dzisiaj; por. Pyl, Geschichte, s. 6.

${ }^{6}$ Zarówno Pyl jak i Hoogeweg piszą o książęcej darowiźnie „locus salis” na rzecz klasztoru, leżących w bagnistych terenach przy ujściu rzeki do zatoki, jednak Hoogeweg datuje darowiznę na 
Gdy na wskutek działań wojennych prowadzonych między Danią a Brandenburgią w roku 1198 klasztor Dargun został zniszczony, rok później przeprowadzono relokację klasztoru na własność ziemską znajdującą się przy pomorskim solnisku. Tym samym nowy klasztor przejął nazwę od rzeki, przy której się znajdował. W późniejszym okresie rzeka (i klasztor) występowały pod różnymi adaptacjami nazw: Hilda, Hylda, Jlda, Ylda i w końcu Elda, z którego między XIII a połową XIV wieku wyłoniła się nazwa „Eldena”. Około 40 lat po fundacji klasztoru Eldena opat konwentu Andreas - ze względu na niepewną sytuację polityczną na pograniczu księstw - zwrócił się zarówno do księcia rugijskiego Wisława II, jak i do księcia pomorskiego Warcisława III z prośbą o udzielenie klasztorowi prawa urządzania targu na terenie własności klasztornej. Książęta w 1241 roku udzielili zgody. Podczas gdy Warcisław udzielił prawa bez ograniczeń, Wisław pozwolił na urządzanie targu jedynie raz w tygodniu. W strategicznie korzystnym dla osadnictwa miejscu położonym między wspomnianą już wyżej rzeką graniczną Ryck (=reka/rzeka) a solniskiem powstała osada Greifswald (oppidum Gripheswald), po raz pierwszy wzmiankowana $\mathrm{w}$ źródłach księcia pomorskiego Warcisława III w 1248 roku, przy czym książę potwierdził, że Greifswald stanowi własność klasztoru Eldena. Ściągano osadników z Danii, z różnych regionów Cesarstwa oraz zza Odry. Opactwo było bardziej związane z księciem pomorskim niż rugijskim, co widać po nazewnictwie i herbie osady Greifswald, które nawiązują do gryfa (Greif), od którego książęta pomorscy z dynastii Gryfitów zaczerpnęli swą nazwę. W 1249 roku książę przejął od klasztoru Greifswald w lenno, otrzymując sądownictwo i wszelkie prawa, jednak dzielił się z klasztorem zyskami handlowymi. Opactwo zostało zaś zwolnione z obowiązku płacenia cła. W 1250 roku książę nadał oppidum lubeckie prawa miejskie ${ }^{8}$. W kilkanaście lat później miasto było już członkiem hanzy (pierwsza wzmianka pochodzi z 1278 roku). ${ }^{9}$ Opactwo Eldena utrzymywało odtąd $\mathrm{z}$ miastem intensywne stosunki handlowe, przejęło nad kościołami miejskimi patronat oraz posiadało na terenie miasta dwory miejskie (Stadthof), w których przetrzymywało towar przeznaczony na handel i w których mogli przez krótki czas przebywać zakonnicy odpowiedzialni za finalizację transakcji handlowych, co było jednym ze źródeł bogactwa zakonu (obok monopolu na utrzymywanie młynów i rybołówstwa). Zakon utrzymywał w późniejszym okresie ścisłe kontakty z mieszczaństwem Greifswald, z którego rekrutowała się spora część zakonników. W Greifswald alumni opactwa od roku 1455/1456 studiowali na uniwersytecie ${ }^{10}$. Te ścisłe kontakty były utrzymywane aż do reformacji, zatem młodsze pokolenie cystersów było również podatne na wpływ nauki M. Lutra, na którą sukcesywnie otwarło się greifswaldzkie mieszczaństwo.

1207 roku, być może chodzi o dwie różne darowizny? Por. Pyl, Geschichte, s 5; Hoogeweg, Die Stifter (Bd. 1), s. 468.

${ }^{7}$ Pyl, Geschichte, s. 5-6.

${ }^{8}$ Hoogeweg, Die Stifter (Bd. 1), s. 467-469.

${ }^{9}$ D. Kattinger, Die Stadtentwicklung vom Ende des 13. Jahrhunderts bis 1500, w: Greifswald. Geschichte der Stadt, Red. H. Wernicke, Schwerin 2000, s. 37-38; T. Brück, Die Greifswalder Schiffahrt im Spätmittelalter und in der frühen Neuzeit (1250 bis 1774), w: Greifswald, s. 235 oraz s. 241.

${ }^{10}$ Bulach, Die städtischen Beziehungen, s. 50-70. 
Kolejnym opactwem cysterskim na Pomorzu Zaodrzańskim był klasztor Neuenkamp (obecnie: Franzburg), położony w pobliżu późniejszego miasta hanzy Stralsund. Konwent powstał w roku 1231 jako dependencja nadreńskiego opactwa (Alten-)Kamp, najstarszego niemieckiego opactwa cystersów, założonego w 1123 roku przez opactwo Morimond ${ }^{11}$. Fundując klasztor, księciu rugijskiemu Wisławowi I zależało na prężnym rozwoju zakonu, dlatego zaproszenie skierował nie do bliżej położonych klasztorów, ale do najstarszego niemieckiego opactwa nadreńskiego, które cieszyło się dobrą reputacją. Nowe opactwo miało zapewnić rodzinie książęcej nie tylko zbawienie duszy (,,pro spe salutis nostre et parentum nostrorum"), ale również przyspieszyć rozwój regionu, zatem książę wyposażył je w posiadłości ziemskie położone ,super rivum, qui vocatur Campenitz” (obecnie: Blinde Trebel) w pobliżu wioski Richtenberg. Do nowej fundacji należała wioska wraz z patrocinium kościelnym, znajdujące się w pobliżu solnisko, pobliskie stawy, lasy oraz dalsze przywileje, m.in. prawo osiedlania na ziemiach klasztornych („,cuiuscunque gentis et cuiuscunque artis homines”) ${ }^{12}$. Klasztor, który pierwotnie został nazwany „Rosetum”, już niebawem, bo po 1231 roku, był określany jako „,novus campus” ${ }^{\prime 3}$. Opactwo w kolejnych latach przejmowało dalej położone wioski (wraz z prawem dziesięciny), szczególnie zainteresowane było jednak pozyskaniem prawa połowu ryb i budowy młynów, co - mając monopol na tę gałęź gospodarki - stanowiło dochodowy interes i było podstawą stabilności finansowej $^{14}$. Neuenkamp podzielił los licznych klasztorów pomorskich, przed rokiem 1300 został bowiem przeniesiony do bardziej strategicznego miejsca, a byłemu kościołowi klasztornemu biskup Schwerina (Neuenkamp leżał na terenie diecezji Schwerin) przydzielił beneficja kościelne, przez co klerycy konwentualni nadal obsługiwali swoją byłą świątynię. ${ }^{15}$ Opactwo Neuenkamp zacieśniło kontakty handlowe z pobliskim miastem hanzy Stralsund, w którym utrzymywało własne dwory miejskie. Losy opactwa oraz ścisłe kontakty z mieszczaństwem Stralsund były związane w podobny sposób jak w przypadku klasztoru Eldena i miasta Greifswald, zatem również reformacja odbiła się na sytuacji klasztoru ${ }^{16}$.

W 1296 roku książę rugijski Wisław II podarował konwentowi Neuenkamp wyspę Hiddensee (będącą częścią Rugii) w celu założenia tam konwentu pw. św. Mikołaja. Fundacja otrzymała prawo połowu ryb, wioskę Zarrenzin i prawo sądownictwa na wyspie Hiddensee. Ponadto książę sprzedał klasztorowi Neuenkamp wyspę Zingst, która miała przejść na własność nowego klasztoru cystersów,

${ }^{11}$ Pomijam w niniejszej publikacji żeńskie klasztory cysterek. Warto jednak wspomnieć, że założony w roku 1193 konwent cysterek w Bergen na wyspie Rugii należał do najstarszych lokacji zakonu cysterskiego na Pomorzu Zaodrzańskim. Hoogeweg, Die Stifter (Bd. 1), s. 92-163.

${ }^{12}$ Bulach, Die städtischen Beziehungen, s. 85-86.

${ }^{13}$ Tamże, s. 85 (przypis nr 374); Hoogeweg, Die Stifter (Bd. 2), s. 123.

${ }^{14}$ Szczegółowy opis dot. powiększania własności ziemskich przedstawia Hoogeweg, Die Stifter (Bd. 2), s. 123-133.

${ }^{15}$ Bulach, Die städtischen Beziehungen, s. 87; Hoogeweg, Die Stifter (Bd. 2), s. 133.

${ }^{16}$ Bulach, Die städtischen Beziehungen, s. 105-126. 
a także obdarował konwent dalszymi przywilejami. Fundację klasztorną musiał zatwierdzić biskup duńskiej diecezji Roskilde, na którym terytorium kanonicznym znajdowała się wyspa Hiddensee ${ }^{17}$.

Ostatnim i najmłodszym klasztorem cysterskim na Pomorzu Zaodrzańskim był Słup (Stolpe) położony kilka kilometrów od Anklam (od 1283 roku miasto hanzy). Słup był najstarszym klasztorem na Pomorzu Przednim, został bowiem założony już w 1153 roku przez biskupa pomorskiego Wojciecha I, pierwotnie jako klasztor benedyktynów. Decyzja o sprowadzeniu z opactwa Bergen pod Magdeburgiem benedyktynów przez biskupa Wojciecha spowodowana była prawdopodobnie sentymentem do tego zakonu, ponieważ jego „nauczyciel i mistrz” - misjonarz Pomorza, biskup Otton z Bambergu - w szczególny sposób był związany $\mathrm{z}$ benedyktynami ${ }^{18}$. Zakonnicy działali w Słupie jednak tylko przez półtora wieku. W 1304 roku cystersi przejęli klasztor, w którym działali do kasaty w roku $1535^{19}$. Ze względu na fakt, że nie zachowały się archiwalia opisujące przebieg kasaty tego klasztoru w czasach reformacji, w poniższym artykule przedstawiony będzie los klasztorów w Eldena, Neuenkamp i Hiddensee.

\section{Kasaty opactw cysterskich}

\section{Greifswald i Eldena}

Kasaty klasztorów pomorskich $\mathrm{w}$ czasie reformacji są nieporównywalne z późniejszym przebiegiem w Prusach w 1810 roku. XIX-wieczne zeświecczenie było wprawdzie procesem dhużej przygotowywanym, lecz przeprowadzonym z zaskoczenia. Królewski edykt sekularyzacyjny został tajnie podpisany i opublikowany po zarekwirowaniu dóbr kościelnych. Wcześniej wyznaczeni urzędnicy państwowi zostali jednocześnie wysłani do danego ośrodka, aby uniemożliwić klerowi szybkie zabezpieczenie mienia. Kasaty z roku 1810 były zatem aktem siły państwa nad Kościołem, a zakony stanowiły bezbronne bastiony katolicyzmu. Natomiast sytuacja $\mathrm{w}$ dobie reformacji była zupełnie inna. Jeszcze przed wystąpieniem Lutra w konwentach była widoczna narastająca w siłę erozja, spowodowana wchłonięciem przez część (młodszego) kleru nauki humanistów, częściowo skrajnie atakującą Kościół katolicki, oraz scholastycznie nastawione studia teologiczne na uniwersytetach. Po publicznym wystąpieniu M. Lutra oraz jego współpracowników (Melanchtona, Bugenhagena) w klasztorach dochodziło do podziałów, część zakonników bowiem ochoczo przejmowała nową naukę, a część silnie ją zwalczała. Luteranizm zaczął się zatem powoli i niepostrzeżenie rozprzestrzeniać wewnątrz struktur kościelnych, zatem postanowienia sejmu trzebiatowskiego z roku 1534 wprowadzające luteranizm jako religię państwową w księstwie pomorskim były już tylko aktem formalnym. To tłumaczy, dlaczego elitę protestanckich kaznodziei i pastorów pomorskich w pierwszym pokoleniu

\footnotetext{
${ }^{17}$ Hoogeweg, Die Stifter (Bd. 2), s. 1-4.

${ }^{18}$ Tamże, s. 655.

${ }^{19}$ Tamże, s. 662.
} 
stanowili ekszakonnicy. Nie bez znaczenia jest też mądra i strategiczna postawa reformatora pomorskiego Bugenhagena, który pozyskiwał multiplikatorów reformacji wśród młodego kleru, oferując im dogodności finansowe.

Proces szerzenia reformacji zapoczątkowały trzy kluczowe postacie życia kościelnego w Trzebiatowie oraz w klasztorze norbertanów w Białobokach koło Trzebiatowa: trzebiatowski proboszcz Otto Sclutow, opat klasztoru norbertanów Johann Boldewan i Jan Bugenhagen - późniejszy „Doctor Pomeranus” oraz główna postać reformacji na Pomorzu ${ }^{20}$. Mało wiadomo na temat opata J. Boldewana. Na początku XVI wieku został immatrykulowany na uniwersytecie w Greifswald i w roku 1517 został opatem. Po przejściu na luteranizm, na wskutek postanowień edyktu wormackiego potępiającego działalność „innowierców” i zdecydowane działania antyluterańskie nowego biskupa kamieńskiego Erazma von Manteuffel, który został następcą zmarłego w 1521 roku biskupa Marcina von Karith, opuścił wraz z J. Bugenhagenem Pomorze i udał się do Wittenbergi, a później działał w kościele ewangelickim w Hamburgu ${ }^{21}$. Natomiast J. Boldewan i J. Bugenhagen poznali się jako studenci teologii w Greifswaldzie, gdzie J. Bugenhagen studiował w latach 1502-1504. Obydwaj zetknęli się na początku studiów z humanistą Hermannem von dem Busche, zwolennikiem Erazma z Rotterdamu. Hermann von dem Busche wykładał w Greifswald do 1502 roku, po czym przejął katedrę retoryki i poetyki na uniwersytecie w Wittenbergii i stał się w późniejszych latach zagorzałym zwolennikiem M. Lutra. Dzięki temu młodzi studenci dogłębnie poznali nauki humanistów, a przede wszystkim Erazma. Wpływ ten utwierdził w nich przekonanie, że nauki teologiczne powinny bazować na podstawie znajomości Ewangelii oraz nauki św. Augustyna, a nie tomistycznej scholastyce. W 1504 roku J. Bugenhagen został rektorem szkoły łacińskiej w Trzebiatowie, szerząc w niej humanistyczny program edukacyjny, dzięki któremu szkoła stała się słynna w całym regionie. W 1509 roku przyjął święcenia kapłańskie i objął funkcję wikariusza w trzebiatowskim kościele. Ponadto w 1518 roku został nauczycielem teologii w klasztorze w Białobokach ${ }^{22}$. Proboszcz O. Sclutow, opat J. Boldewan i J. Bugenhagen utrzymywali intensywne kontakty, spotykając się regularnie na rozmowach. Gdy O. Sclutow otrzymał z Lipska druk wydanego w 1520 roku przez M. Lutra głównego traktatu teologicznego O niewoli babilońskiej Kościoła, w którym reformator polemizował z nauką Kościoła o siedmiu sakramentach, przekazał go J. Bugenhagenowi, którego szanował za przymioty intelektu. Według późniejszych relacji kronikarskich J. Bugenhagen po pobieżnym przejrzeniu dzieła był zbulwersowany herezją M. Lutra. Jednak wziął ze sobą traktat do domu, gdzie zapoznawszy się dokładnie z jego treścią, następnego dnia oznajmił towarzyszom rozmów, że cały świat jest w błędzie, a jedynie

${ }^{20}$ Pommersches Archiv der Wissenschaften und des Geschmaks, Bd. 4, red. J.Ph.A. Hahn, G.F. Pauli, Szczecin, Anklam 1785, s. 156; Pyl, Geschichte, s. 520.

${ }^{21}$ J.H. Biesner, Geschichte von Pommern und Rügen. Nebst angehängter Specialgeschichte des Klosters Eldena, Greifswald 1839, s. 211; H.G. Leder, Johannes Bugenhagen Pomeranus Nachgelassene Studien zur Biographie, w: Greifswalder theologische Forschungen, Bd. 15, Red. V. Gummelt, Greifswald 2008, s. 111.

${ }^{22}$ Pyl, Geschichte, s. 520; Leder, Johannes Bugenhagen, s. 11. 
M. Luter odkrył prawdę. Jan Bugenhagen wyjaśnił swoim towarzyszom istotę nauki M. Lutra, przez co stali się oni zagorzałymi zwolennikami reformacji 23 . Powyższa relacja wywodzi się z późniejszych zapisek kronikarzy ewangelickich, którzy przedstawili ją w formie retoryki polemicznej, dlatego też należy odnieść się do niej z dużą powściągliwością. Według najnowszych badań historycznych, J. Bugenhagen zapoznał się ze wspomnianą publikacją M. Lutra pod koniec 1520 roku $^{24}$. W ten sposób idee reformacji subtelnie wtargnęły do tego znaczącego ośrodka edukacyjnego na Pomorzu i zaczęły powoli rozprzestrzeniać się w kolejnych miastach nadodrzańskich i okolicach Wolina.

W pierwszych latach po opublikowaniu tez M. Lutra nie zanosiło się na zmiany polityczne. Po śmierci księcia pomorskiego Bogusława X Wielkiego w 1523 roku jego syn Jerzy I $(\uparrow 1531)$ kontynuował dzieło ojca i starał się bronić interesów Kościoła katolickiego. Początkowo Greifswald było odporne na idee reformacji, nie tylko dzięki kręgom uniwersyteckim. Biskupi kamieńscy Marcin von Karith (1498-1521) i jego następca Erazm von Manteuffel (1521-1544) starali się odeprzeć naukę M. Lutra m.in. poprzez aktywne działania na rzecz intensywnej edukacji alumnów w Greifswald. Wspomniana wcześniej ironia losu, na wskutek której instytucje kościelne przyczyniły się niechcąco do rozwoju reformacji, uwidoczniła się również w przypadku Greifswaldu i opactwa Eldena. Szerzenie się reformacji na Pomorzu, Brandenburgii i w sąsiednich regionach doprowadziły do zmniejszenia się liczby powołań. Klasztory przyjmowały coraz mniej nowicjuszy, ponieważ ideał życia monastycznego nie był już popularny wśród młodzieży. Sytuacja stała się tak dramatyczna, że według opata klasztoru Eldena, Enwalda Schinkela, konwentowi groziło wymarcie. Jedynym rozwiązaniem według niego było przyjęcie kandydatów do zakonu z zachodnich regionów Rzeszy, które nie znalazły się jeszcze pod wpływem reformacji. Były to w jego mniemaniu Westfalia oraz Niderlandy, gdzie życie religijne (katolickie) cieszyło się do niedawna rozkwitem, w latach 1403-1485 bowiem ufundowano tam 12 nowych klasztorów cysterskich $^{25}$.Według zapisek młodego zakonnika cysterskiego Antona Remmelding, urodzonego ok. 1513 roku w księstwie Geldrii (Reńsko-Westfalskim Okręgu Rzeszy), opat E. Schinkel w 1528 roku wysłał do Deventer zakonnika i uczonego z macierzystego opactwa, Lorenza Brincken (Brink), z misją uzyskania zgody rektora słynnej deventerskiej szkoły Jana Lippiusa na wysłanie młodych alumnów do Eldeny. Początkowo rektor J. Lippius nie był przychylnie nastawiony do tej prośby, bojąc się o zły wpływ reformacji na młodych zakonników na dalekim Pomorzu. Jednak L. Brincken, uzyskawszy wsparcie pobliskiego opactwa cysterskiego w Burlo koło Borken (Westfalia), otrzymał aprobatę rektora. W asyście zakonnika klasztoru Burlo, L. Brincken spotkał się z alumnami wszystkich semestrów, przedstawiając im swoją misję. Złożył im obietnicę przejęcia przez uniwersytet greifswaldzki wszystkich kosztów ich studiów, jeżeli tylko wstąpią do opactwa Eldena jako nowicjusze. Kilku studentów wyraziło wówczas zainteresowanie propozycją. Niektórzy z nich zapewne kierowali się chęcią przygody,

\footnotetext{
${ }^{23}$ Pommersches Archiv, Bd. 4, s. 156-157.

${ }^{24}$ Leder, Johannes Bugenhagen, s. 20 oraz s. 25.

${ }^{25}$ Pyl, Geschichte, s. 521-524.
} 
opuszczając rodzinne strony. Między nimi był ok. 15-letni Anton Remmelding. W dniu 30 maja 1528 roku grupa udała się w podróż do Eldeny ${ }^{26}$. Starając się pozyskać młodych zakonników z „nieskażonego” reformacją regionu i tym samym mając nadzieję na wsparcie konwentu w przyszłych burzliwych latach, opat E. Schinkel nie mógł wiedzieć, że sam przyczyni się do sekularyzacji konwentu. Przybyły A. Remmelding w przeciągu paru lat poróżnił klasztor, stając się promotorem przejścia młodego pokolenia zakonników na stronę M. Lutra, przez co kasata zakonu przez książęta pomorskie stała się jedynie zakończeniem trwającej już dłuższy czas agonii konwentu. Anton Remmelding został z czasem ważną postacią we wspólnocie luterańskiej na Pomorzu, ponieważ w latach 1556-1584 piastował urząd pastora w kościele farnym (dawnej kolegiacie NMP) w Stargardzie.

Dokładny przebieg wyboru alumnów w Deventer, podróż do opactwa Eldena oraz późniejszy konflikt w konwencie, przejście części zakonników na stronę reformacji i przebieg kasaty znany jest dzięki obszernej relacji A. Remmeldinga. Wprawdzie jego notatki nie zachowały się $\mathrm{w}$ oryginale, ale zostały opracowane na początku XVII wieku. Wykorzystał je i zacytował w pomorskiej kronice kościelnej szczeciński ewangelicki kronikarz Daniel Cramer ${ }^{27}$. Mimo stronniczości autora i kronikarza można jednak poznać sytuację, w której znaleźli się zakonnicy po konfrontacji z nauką reformatorów oraz ich zachowania. Nawet gdy A. Remmelding zbyt bardzo uwypuklał swoją rolę w przeprowadzeniu reformacji klasztoru i przedstawiał wydarzenia w korzystnym dla protestantyzmie świetle, warto zaprezentować tutaj również luterańską interpretację faktów, ponieważ ukazane zostały podziały $\mathrm{w}$ konwencie i zachodzące $\mathrm{w}$ nim zmiany ideowe.

Wysłannik L. Brincken oraz alumni wyruszyli z Deventer i dotarli do opactwa Doberan koło Rostocku. Kandydaci zatrzymali się tam na dwa tygodnie, ponieważ L. Brincken udał się sam do Eldeny, konsultując z opatem dalsze postępowanie. Obawiał się on kontynuowania podróży przez tereny opanowane przez reformację, m.in. miasta hanzy Rostock i Stralsund, których mieszczaństwo już od roku 1523 zaczęło przechodzić na nową wiarę. Po naradzie z opatem E. Schinklem, L. Brincken wrócił po alumnów i przyprowadził ich do Eldeny, wybierając boczne szlaki ${ }^{28}$. Na miejscu opat zdecydował, że wysłanie alumnów na studia do Greifswald jest zbyt ryzykowne. Chciał zaczekać do werdyktu Sejmu Rzeszy w Augsburgu (1530), mając nadzieję na korzystne rozwiązanie polityczne

${ }^{26}$ Pyl, Geschichte, s. 524-526; D. Cramer, Das Grosse Pomrische Kirchen-Chronicon: Das ist Beschreibung Und Außführlicher Bericht, was sich fürnemblich in Religions Sachen, von Enderung der Heydenschafft her, im Land zu Pomren, und zugehörigem Fürstenthumb Rügen, auch Graff- und Herrschafften, bey noch wehrendem Christenthumb..., Bd. 3, Szczecin 1628, s. 46-47 oraz tenże, Das Grosse Pomrische Kirchen-Chronicon, 73-75, s. 88-89; G.H.M. Delprat, Die Bruderschaft des gemeinsamen Lebens. Ein Beitrag zur Geschichte der Kirche, Litteratur und Pädagogik des vierzehnten, fünfzehnten und sechzehnten Jahrhunderts, Leipzig 1840, s. 179-182.

${ }^{27}$ D. Cramer, Pommerische Chronica // Das ist Beschreibung und ausführlicher Bericht / wie anfenglich durch Bischoff Otto von Bamberg / die Pommern aus heidnischer Blindheit zum Christentumb belehret..., Frankfurt am Main 1602, s. 46-51; s. 61-62 oraz tenże, Das Grosse Pomrische Kirchen-Chronicon, s. 73-75, s. 88-89.

${ }^{28}$ Biesner, Geschichte, s. 420-422; Pyl, Geschichte, s. 525-526. 
w kwestii luterańskiej. Alumni pobierali więc nauki teologiczne w opactwie. Ich nauczycielem był kapelan, magister niejaki Henryk (Henricus), który nie stronił od alkoholu i innych przyjemności. Brak dyscypliny i odpowiedniego poziomu nauczania źle rzutował na młodych podwładnych, ci bowiem koncentrowali się na młodzieńczych żartach, m.in. wykradali się nocą z klasztoru do ogrodu, aby zrywać owoce z drzew czy też niszczyć ptasie gniazda, przy okazji uszkadzając habity ${ }^{29}$. W następstwie wspomnianych wydarzeń opat przydzielił alumnom wicegwardiana konwentu, o którym A. Remmelding nie wyrażał się po latach zbyt pochlebnie, był to „dosyć przemądrzały mnich, wewnętrzną pychą śmierdział jak kozioł" i który „w swoim mniemaniu był wielce słynnym filozofem, równy Arystotelesowi”"30. Wykłady odbywały się z zakresu Psalmów, Ewangelii i pism paulińskich z perspektywy teologii scholastycznej. Wicegwardian surowo przestrzegał dyscypliny zakonnej i żył w ascezie. Chcąc być dla wychowanków przykładem do naśladowania, wstawał wraz z innym zakonnikiem o północy, wstawiał zapaloną świeczkę do okna kościelnego i modlił się za grzechy swoje i ludzkie, spełniając modlitwę Psalmu 119,62: „Wstaję o północy, aby Cię wielbić za słuszne Twoje wyroki", po czym - jak po latach zapisał pogardliwie A. Remmelding - ,rychle położyli się w ciepłej izbie, spali i chrapali jak tłuste świnie, tak że ich łatwo można było słyszeć na zewnątrz" ${ }^{31}$. Część studentów sympatyzująca ze zwolennikami reformacji nie była podatna na surowe egzekwowanie dyscypliny, część zaś wrogo nastawiona do nauki i zwolenników M. Lutra starała się nadgorliwie przestrzegać ascezy, wyprzedzając mistrza. Do ostatniej grupy należał A. Remmelding, który wraz ze współbratem Johannem Wessenem jedli zgniłe owoce, wkładali kamyki do trzewików, pościli w celu umartwiania ciała i spędzali czas na modlitwie, podczas gdy inni kładli się już spać. Starając się wzmóc ascezę, A. Remmelding wielokrotnie prosił przeora o zamknięcie go w karcerze czy wysłanie na odludne miejsce, aby mógł wieść życie eremity. Ponieważ nie uzyskiwał na to zgody, wpadł w stan głębokiego przygnębienia. Cierpiał na halucynacje, widział duchy i prześladowały go myśli samobójcze ${ }^{32}$. Pomimo młodego wieku opat powierzył mu po pierwszym roku nowicjatu liczne urzędy klasztorne, mając nadzieję, że odpowiedzialne zadania rozproszą negatywne myśli i poprawią samopoczucie. Anton Remmelding uzyskał funkcję ,servitoris Ecclesiae”, sukcentora i podzakrystiana. ${ }^{33}$

Przebieg Sejmu Rzeszy w Augsburgu w 1530 roku był zadowalający dla klasztorów pomorskich. Wprawdzie frakcja M. Lutra i F. Melanchtona zaprezentowała tam swe Wyznanie augsburskie, które stało się fundamentem przyszłego Kościoła ewangelickiego, jednak pozycja cesarza Karola V jako protektora wiary katolickiej wzrosła w siłę po zwycięskiej ofensywie przeciwko Francji i pojednaniu się z papieżem, co zakończyło waśnie ze Stolicą Apostolską. Cesarz zdecydował się siłą sthumić ruch reformatorski, do czego potrzebował sojuszu książąt katolickich.

\footnotetext{
${ }^{29}$ Pyl, Geschichte, s. 525-526; Cramer, Das Grosse Pomrische Kirchen-Chronicon, s. 73.

${ }^{30}$ Cramer, Das Grosse Pomrische Kirchen-Chronicon, s. 73.

31 Tamże.

32 Tamże, s. 74.

${ }^{33}$ Tamże.
} 
Książę pomorski Jerzy I przystąpił do antyluterańskiego sojuszu. Również polityczna pozycja księcia Jerzego wzrosła w siłę po podpisaniu w 1529 roku umowy w Grimnitz, która zakończyła wielopokoleniowy spór między pomorskimi Gryfitami a brandenburskimi Hohenzollernami o sukcesję w księstwie na korzyść rodu pomorskiego. Rok później cesarz Karol V obdarzył księcia lennem koronnym, które w kolejnych latach zostało poszerzone o bezpośrednią przynależność do Rzeszy. Również młodszy brat Jerzego, Barnim IX (Pobożny), z którym jako współwładca dzielił rządy księstwem, początkowo był przychylnie nastawiony do stronnictwa katolickiego. Odmówił więc protestanckim książętom wstąpienia do związku szmalkaldzkiego i aprobował antyluterańskie postanowienia Sejmu Rzeszy w Augsburgu. W tej sytuacji wydawało się, że przyszłość Cesarstwa związana będzie z Kościołem katolickim, a zakony na Pomorzu będą niezagrożone ${ }^{34}$.

Jednak sytuacja polityczna i wyznaniowa szybko się zmieniła. Ciągłe zagrożenie najazdu tureckiego uzależniało cesarza finansowo od protestanckich książąt. Po zajęciu Węgier przez Turków cesarz został zmuszony do podpisania w Norymbergii pokoju religijnego (w 1532 roku), co skonsolidowało wyznanie augsburskie. Jednocześnie zupełnie nieoczekiwanie zmarł w 1531 roku książę pomorski Jerzy I. Tym samym klasztory pomorskie straciły najsilniejszego promotora, jego syn Filip I (Wołogoski) bowiem stał się zwolennikiem reformacji ${ }^{35}$. Również współwładca, stryj Barnim IX zmienił nastawienie w kwestii wyznaniowej. W 1532 roku Barnim przeprowadził podział księstwa. Po losowaniu przejął ziemie położone na wschód od Odry (księstwo szczecińskie), natomiast bratanek Filip I przejął ziemie zachodnie (księstwo wołogoskie). W 1534 roku Barnim zwołał sejm trzebiatowski, na którym książęta wprowadzili reformację na Pomorzu. Tym samym Barnim stał się pierwszym protestanckim księciem pomorskim.

Otwarcie się mieszczan greifswaldzkich na naukę Lutra ściśle związane jest z działalnością reformatora Jana Knipstro (Kniepstrow). Był to dawny franciszkanin, który podczas studiów we Frankfurcie nad Odrą zetknął się z nauką Lutra i stał się jej zwolennikiem. Został za to dyscyplinarnie zesłany do klasztoru pomorskiego w Pyrzycach. Jednak wkrótce zaczął głosić naukę Lutra w Stargardzie. W obawie przed nakazem aresztu wydanym przez biskupa kamieńskiego Manteuffla, zbiegł on w 1525 r. do Stralsund, gdzie działał w miejskim kościele mariackim. W 1531 r. przybył do Greifswald, gdzie wygłaszał poruszające kazania, na skutek czego trzy kościoły miejskie pw. św. Mikołaja, św. Jakuba i NMP już w 1532 r. przeszły w ręce protestantów.

Zachodzące procesy reformacyjne odbiły się również negatywnie w konwencie Eldena. Opat E. Schinkel, przeor Michael Knabe, kapelan Nikolaus Berend i kilku starszych zakonników starało się obronić wspólnotę zakonną przed wpływem reformacji. Było to jednak trudne, gdyż podprzeor Michael był gorliwym zwolennikiem M. Lutra. Pełniąc swoją funkcję, miał wpływ na rozwój duchowy młodych zakonników ${ }^{36}$. W swojej kronice Daniel Cramer relacjonuje, że podprzeor przyczynił się do osobistego spotkania między reformatorami Knipstro-

\footnotetext{
${ }^{34}$ Pyl, Geschichte, s. 528.

35 Tamże, s. 529.

36 Tamże, s. 529-530.
} 
wem, Clemensem Timme, a nowicjuszem A. Remmeldingiem. Młody zakonnik otrzymał od nich postylle M. Lutra, które alumni potajemnie studiowali ${ }^{37}$. Anton Remmelding podchodził z rezerwą do nauki M. Lutra, jednak studiował jego komentarze do Pisma Świętego ${ }^{38}$.

Jego postawa względem nowej nauki szybko się zmieniła i wkrótce stał się zagorzałym zwolennikiem M. Lutra. Ironią losu jest fakt, że to właśnie opat E. Schinkel przyczynił się do tej zmiany w poglądach młodego zakonnika. Na początku 1534 roku wysłał on kilku nowicjuszy, w tym A. Remmeldinga, do biskupa kamieńskiego, który miał im udzielić w Karlinie pierwszych ślubów zakonnych. W Wolinie spotkali oni nieznanego z nazwiska kaznodzieję luterańskiego, z którym prowadzili dysputę teologiczną. Kaznodzieja w swoich wypowiedziach nawiązywał do traktatu dogmatycznego J. Bugenhagena, który powołując się na ojców Kościoła, przekonywał, że to właśnie nauka Kościoła katolickiego, a nie pisma M. Lutra są sprzeczne z podstawowymi prawdami wiary chrześcijańskiej. Konfrontacja z wywodami reformatora wstrząsnęła młodymi zakonnikami. Na początku wielkiego postu alumni złożyli przed biskupem Erazmem von Manteufflem wspomniane już śluby zakonne. Alumnów wysłano do klasztoru w Bukowie Morskim koło Darłowa, gdzie przygotowywali się do kolejnych ślubów zakonnych, które mieli złożyć w Golczewie koło Kamienia Pomorskiego. W klasztorze zetknęli się z kapelanem, który był gorliwym zwolennikiem M. Lutra. Przekazał on młodym alumnom komentarz F. Melanchtona do Listu do Rzymian, który alumni codziennie studiowali ${ }^{39}$.

Po powrocie do opactwa Eldena młodzi zakonnicy zaczęli czytać dzieła ojców Kościoła z biblioteki klasztornej oraz otrzymane potajemnie pisma J. Bugenhagena i F. Melanchtona. Lektura w pełni przekonała ich o racji reformatorów, dlatego też sprzymierzyli się z podprzeorem Michaelem. Jednak opat E. Schinkel i przeor M. Knabe, wierni Kościołowi katolickiemu, nie zauważyli zmiany postawy A. Remmeldinga. Sądząc, że został on utwierdzony w wierze, opat powierzył mu mimo młodego wieku funkcję zakrystiana, co sprawiło, że miał znaczny wpływ na współbraci. Jednak ten celowo zaniedbywał swoje obowiązki w koordynowaniu modlitw zakonnych zgodnie z regułą zakonu i nie budził współbraci na wczesną mszę świętą, za co - jak zapisał w swojej późniejszej relacji - większość konwentu była mu ogromnie wdzięczna ${ }^{40}$.

Z czasem również opat i przeor zdawali sobie sprawę z sytuacji, jednak nie mieli wsparcia ze strony malejącej liczby katolickich profesorów w Greifswald. Liczni profesorowie m.in. Johannes Otto, Johannes Oldendorp, Erasmus Holthuber czy Johannes Hagemeister przeszli na stronę reformacji i działali jako protestanccy wykładowcy akademiccy lub pastorzy. Jeden z najgorliwszych sprzymierzeńców i przyjaciół opata profesor Wichmann Kruse zmarł na początku 1534

${ }^{37}$ Cramer, Das Grosse Pomrische Kirchen-Chronicon, s. 88.

${ }^{38}$ Pyl, Geschichte, s. 530.

${ }^{39}$ Cramer, Pommerische Chronica, s. 61-62; tenże, Das Grosse Pomrische Kirchen-Chronicon, s. 88-89; Pyl, Geschichte, s. 530-531.

${ }^{40}$ Cramer, Pommerische Chronica, s. 62; Pyl, Geschichte, s. 531-532. 
roku, a jedynie prawnicy Henning Lotze i Heinrich Bukow walczyli po stronie Kościoła katolickiego. Wsparcie ze strony książąt pomorskich okazało się z czasem zawodne, gdyż i oni przyjęli protestantyzm.

Reformatorzy protestanccy z J. Bugenhagenem na czele zwalczali wprawdzie Kościół katolicki, jednak stanowczo wypowiadali się za zachowaniem majątku i posiadłości klasztornych w przypadkach, gdzie widzieli taką potrzebę. Tym samym potępiali działalność radykalnych ugrupowań reformatorskich jak nowochrzczeńców w westfalskim Monastyrze czy ikonoklastów. Jan Bugenhagen w grudniu 1534 roku wypowiedział się na sejmie trzebiatowskim za zachowaniem pomorskich klasztorów, przytaczając podobne przypadki w Księstwie Brunszwiku i Lüneburga oraz w Wirtembergii. Postawa J. Bugenhagena nie była jednak bezinteresowna. Reformatorzy mieli plany stworzenia nowych struktur kościelnych i potrzebowali nieruchomości kościelnych w celu adaptacji ich na fary, siedziby administracji i mieszkań dla rodzin ewangelickich kaznodziejów, a przede wszystkim na szkoły dla młodzieży szlacheckiej i mieszczańskiej oraz na miejsca edukacji nowej kadry protestanckiej. Książęta Barnim IX i jego bratanek Filip I nie zgodzili się jednak na te propozycje, mimo że nawet wujek Filipa, Ludwik V Wittelsbach, elektor Palatynatu reńskiego, ostrzegał przed drastycznymi działaniami, jakimi była likwidacja i sprzedaż klasztorów. Obydwaj książęta potrzebowali jednak środków finansowych. Barnim był już zadłużony od czasów wspólnego panowania $\mathrm{z}$ bratem Jerzym, a książę Filip dążył do wyposażenia macochy - księżniczki Małgorzaty brandenburskiej, która wychodziła za księcia Anhalt-Zerbst Jana IV. Już w trakcie podziału księstwa dokonanego w 1532 roku Barnim i Filip uzgodnili, że w razie przeprowadzenia kasaty klasztorów na terenie całego księstwa, podzielą się równo zyskami. Kasata zakonów nie była jednak na Pomorzu nieznanym wydarzeniem. Już w 1523 roku książę Bogusław X stworzył precedens, sekularyzując klasztor norbertanów w Białobokach. Książęta Barnim i Filip nie chcieli jednak przeprowadzać takich działań, obawiając się odwetu ze strony cesarza i księstw katolickich oraz silnego oporu ze strony miast, stanów czy chłopów ${ }^{41}$. Doświadczenia zebrane dekadę wcześniej w południowej części Cesarstwa w ramach wojen chłopskich pokazały, że kwestie wyznaniowe mogą przełożyć się na zamieszki społeczne. Już na sejmie trzebiatowskim przedstawiciele stanu rycerskiego i duchowieństwa gwałtownie protestowali przeciwko decyzji o przeprowadzeniu kasat, a w listopadzie 1535 roku opaci klasztoru cystersów Neuenkamp i klasztoru macierzystego Altenkamp, Johannes Molner i Johannes von Hüls, złożyli do Sądu Kameralnego Rzeszy (najwyższej instancji sądowniczej) pozew przeciwko kasacie klasztoru Neuenkamp ${ }^{42}$. Kwestia procesu zostanie jeszcze przybliżona $\mathrm{w}$ dalszej części artykułu.

Protesty szlachty czy duchowieństwa przeciwko likwidacjom zakonów nie były uwzględniane przez książęta. Przygotowaniami do realizacji kasat kierował kanclerz wołogoski Braun, który oddalał protesty, udzielając katolikom nagany za interwencję. Przeciwnicy kasat doszli więc do przekonania, że decyzje książęce

\footnotetext{
${ }^{41}$ Pyl, Geschichte, s. 532-534.

${ }^{42}$ Niemeck, Die Zisterzienserklöster, s. 285-286.
} 
nie zostaną cofnięte. Opat klasztoru Eldena E. Schinkel ani na sejmie trzebiatowskim, ani w późniejszym okresie nie reagował na zamiary likwidacji konwentu. Prawdopodobnie pogodził się on z planowanymi decyzjami ${ }^{43}$. Postawa opata klasztoru Neuenkamp, który (bezskutecznie) odwołał się do najwyższego sądu Rzeszy, była reakcją wyjątkową.

Kasata klasztorów pomorskich odbyła się $-\mathrm{z}$ wyjątkiem opactwa Neuenkamp - sukcesywnie i bez większego rozgłosu. W przeciwieństwie do kasat pruskich w 1810 roku nie była to nagła akcja, celebrowana przez specjalnego komisarza, który uroczyście odczytywał wspólnocie zakonnej edykt kasacyjny i w trybie natychmiastowym przejmował klucze do klasztoru. Po zakończeniu obrad sejmu trzebiatowskiego książęta zarządzili przeprowadzenie wizytacji wszystkich stanów i kościołów, która miała zostać wykonana osobiście przez nich w asyście J. Bugenhagena ${ }^{44}$.

Kanclerz Braun w każdym pojedynczym przypadku odnosił się do protestów składanych przez szlachtę. Dotyczyły one nie samej kasaty czy przejęcia majątku, lecz kwestii zabezpieczenia finansowego i patronatu nad instytucjami kościelnymi. Spora część zakonników wywodziła się ze szlachty lub mieszczaństwa, a donacje na rzecz klasztorów przez fundatorów wynikały z chęci zabezpieczenia finansowego zakonników wywodzących się $\mathrm{z}$ tych warstw. Ponadto fundatorzy zyskiwali prawo patronatu, zatem nie chcieli się pogodzić z faktem, że wszystkie ich inwestycje bezpodstawnie przepadną. W przypadku klasztorów w miastach książęta podpisywali z magistratami wzajemne ugody (recessus), w których przekazywali władzom miejskim tymczasowe prawo przejęcia dóbr kościelnych i patronatu. Umowa ta obowiązywała aż do podpisania ostatecznej ugody w dniu 2 maja 1558 roku. Natomiast kasaty klasztorów na wsiach książęta Filip i Barnim dokonywali osobiście, udając się do każdego z nich w asyście J. Bugenhagena ${ }^{45}$.

Przebieg likwidacji opactwa Eldena został szczegółowo zrelacjonowany przez A. Remmeldinga, który był naocznym świadkiem tego wydarzenia, jako zakrystianin bowiem przechowywał klucze do paramentów, precjozów i naczyń liturgicznych ${ }^{46}$. Wizytację konwentu przeprowadzili książęta w asyście J. Bugenhagena, który starał się wcześniej, aby w opactwie zorganizować seminarium teologiczne, jednak nie uzyskał na to ich zgody. Dlatego też postanowił wybrać z grona młodych zakonników kandydatów do funkcji pastorów protestanckich, oferując im opłacenie kosztów studiów teologicznych w Wittenberdze. Książęta nie okazali zbytniego szacunku wobec spuścizny kulturowej opactwa Eldena. Na ich żądanie A. Remmelding otworzył szafy zakrystii, w których przechowywane były szaty, naczynia liturgiczne, precjoza, a także pastorały opatów i gotówka (1400 marek). Po zinwentaryzowaniu zbiorów przez radców książęcych jeden z książąt wziął bogaty ornat (casula) wykonany z czerwonego aksamitu i ozdo-

${ }^{43}$ Pyl, Geschichte, s. 534-535.

${ }^{44}$ Cramer, Das Grosse Pomrische Kirchen-Chronicon, s. 91; tenże, Pommerische Chronica, s. 64.

${ }^{45}$ Pyl, Geschichte, s. 535-536.

${ }^{46}$ Poniższa relacja nawiązuje do: Cramer, Pommerische Chronica, s. 64-65; tenże, Das Grosse Pomrische Kirchen-Chronicon, s. 91-92; Pyl, Geschichte, s. 535-537. 
biony w kwiaty, po czym rzucił go A. Remmeldingowi, aby zachował go jako napiwek. Obdarowany nie przyjął podarunku, odpowiadając, że do takiego odzienia potrzebna jest identyczna torba. Jak napisał, dzięki takiemu zachowaniu został wybrany wraz z paroma młodszymi zakonnikami z opactw Eldena i Neuenkamp do odbycia protestanckich studiów teologicznych w Wittenberdze.

Opat E. Schinkel, będąc już w podeszłym wieku, bez oporu zaakceptował wszystkie warunki, jakie książęta postawili jemu oraz nielicznym już pozostałym członkom konwentu, którzy nie zgodzili się przyjąć luteranizmu. Do końca życia mogli oni pozostać w klasztorze. Zadbano również o ich wsparcie finansowe. Ponadto opat mógł utrzymywać służbę na koszt książąt. Według relacji A. Remmeldinga E. Schinkel otrzymywał roczną wypłatę 30 guldenów, a w rejestrze urzędowym z lat 1543/1544 zanotowano, że wypłacono mu deputat 75 marek. Przeor M. Knabe otrzymywał roczny deputat 15 marek, ponadto kolejne 15 marek na dalsze koszty (,„zum Talar”). Kapelan N. Berend otrzymywał wypłatę deputatu rocznego 15 marek. Pensję roczną o niewiadomej wysokości odbierał również archidiakon Hermann Schröder. Ponadto wypłacano mniejsze sumy na jedzenie, ubranie i opłatę służby. Pozostali zakonnicy wprawdzie nie mieli problemów finansowych, jednak dotkliwie brakowało im życia religijnego, ponieważ prawie wszyscy młodzi zakonnicy opuścili zakon, a w kościele poklasztornym zaniechano odprawiania katolickiej liturgii. Kościół został włączony do nowej parafii ewangelickiej, do której należały też świątynie w pobliskich miejscowościach Wyck i Weitenhagen. Pozostali mnisi żyli w zeświecczonym klasztorze przez dekadę. Zachowane zapiski sugerują, że ostatnim zakonnikiem pozostałym przy życiu był przeor M. Knabe, który pieczołowicie dbał o bibliotekę klasztorną. Zachowany z roku 1547 ręczny komentarz wpisany na marginesie jednej z ksiąg bibliotecznych stanowi ostatni ślad po konwencie. Wynika z niej, że dawny przeor konwentu został osierocony (orfanus), a $\mathrm{z}$ treści księgi zawierającej m.in. wywody na temat duchowego przygotowania do śmierci wynika, iż być może życie przeora dobiegało wtedy końca ${ }^{47}$.

Po śmierci ostatniego zakonnika opactwa Eldena bibliotekę klasztorną przeniesiono do pałacu księcia w Wołogoszczy. Majątek ziemski klasztoru wraz z lasami, młynami i stawami przejął nowo powstały Urząd Książęcy Eldena ${ }^{48}$. Główny administrator zarządzający urzędem otrzymał tytuł hetmana książęcego (,herzoglicher Hauptmann”). Budynek klasztorny został przekształcony na pałac. Dalszy los byłego opactwa nie był jednak szczęśliwy, co można powiedzieć praktycznie na temat wszystkich klasztorów pomorskich. Skutki przebiegu wojny trzydziestoletniej były dla Eldeny dramatyczne. W 1627 roku i ponownie w 1633 roku armia generała Wallensteina zdewastowała Greifswald i budynki poklasztorne. Jednocześnie wymierał książęcy ród Gryfitów. Ostatni książę Bogusław XIV (†1637) krótko przed śmiercią przekazał majątek poklasztorny na własność

${ }^{47}$ Cramer, Das Grosse Pomrische Kirchen-Chronicon, s. 91-92; Biesner, Geschichte, s. 427; Pyl, Geschichte, s. 537-539.

${ }^{48}$ Pełny wykaz majątku klasztornego w: Biesner, Geschichte, s. 430-440. Ponadto autor bardzo obszernie prezentuje historię byłego opactwa, łącznie z dochodami i wydatkami, między 1533 a 1633 rokiem. Por. tamże, s. 441-551. 
uniwersytetu greifswaldzkiego. Władze uniwersyteckie początkowo wzbraniały się przed jego przyjęciem, gdyż budynki były zdewastowane, a majątek zadłużony. Jego część została wcześniej sprezentowana księżnej Sofii Jadwidze (matce ostatniego wołogaskiego księcia Filipa Juliusza) lub wydzierżawiona przez osoby prywatne. Sytuacja prawno-własnościowa zatem była skomplikowana. Mimo zadłużenia władze uniwersytetu przyjęły nieruchomość, aby uratować tę spuściznę kulturową dla przyszłych pokoleń. Uroczysty akt przekazania własności nastąpił w marcu 1634 roku. Dawne opactwo przez ponad 200 lat należało do uniwersytetu (1634-1835). Kolejne wojny coraz dotkliwiej doświadczały kompleks pocysterski. Były to wojna szwedzko-brandenburska (1659-1678), III wojna północna (1700-1720), wojna 7-letnia (1756-1763) oraz wojny napoleońskie (1806-1815). Po kongresie wiedeńskim w 1815 roku Pomorze Zaodrzańskie zostały przejęte przez Prusy, które przekształciły kompleks poklasztorny od 1835 roku w państwową akademię rolniczą. Budynek konwentu został zniszczony w trakcie wojny trzydziestoletniej, ponieważ po dewastacji wojennej przeprowadzonej przez armię Wallensteina w 1633 roku Szwedzi wykorzystali cegły z południowego i zachodniego skrzydła na budowę wałów obronnych. Kościół poklasztorny był wykorzystywany jeszcze do 1672 roku. Według relacji jeszcze w 1722 roku katoliccy duchowni i wierni nawiedzali budynek poklasztorny i odprawiali tam liturgię. Budynek był już wtedy ruiną, w 1684 roku bowiem komendant miasta Stralsund nakazał wybrać z budynków poklasztornych 17000 cegieł. Starania pojedynczych profesorów w celu restaurowania kościoła pod koniec XVII wieku nie powiodły się. Wręcz przeciwnie, w 1728 roku władze uniwersytetu rozebrały mury, wykorzystując materiał budowlany na postawienie budynków administracyjnych w Eldenie i w centrum Greifswaldu. Zachowała się jedynie zachodnia część nawy głównej kościoła, południowe ramię nawy poprzecznej i wschodnie skrzydło budynku konwentu. Dopiero po 1828 roku zaczęto postrzegać ruinę jako pomnik architektury sakralnej, ktory stoi do dzis ${ }^{49}$.

Po przeprowadzeniu wizytacji reformator J. Bugenhagen zaczął tworzyć struktury nowego kościoła. Główną funkcją administracji kościelnej był urząd superintendenta generalnego. Jan Bugenhagen pragnął pozyskać na to stanowisko biskupa ordynariusza egzystującej jeszcze diecezji kamieńskiej, Erazma von Manteuffla. Ten jednak stanowczo odmówił, gdyż pozostał wierny Kościołowi katolickiemu ${ }^{50}$. Ze względu na to funkcję podzielono i dla każdej części księstwa pomorskiego mianowano dwóch superintendentów. Superintendentem generalnym pomorsko-szczecińskim został Paul vom Rode, a pomorsko-wołogoskim Jan Knipstro ${ }^{51}$.

\section{Stralsund i Neuenkamp oraz Hiddensee}

Proces przyjmowania przez Pomorzan protestantyzmu nie przebiegał wszędzie jednakowo. Greifswald był typowym przykładem miast pomorskich, gdzie reformacja szerzyła się sukcesywnie przez wiele lat i powoli obejmowała wszyst-

\footnotetext{
${ }^{49}$ Biesner, Geschichte, s. 427; Pyl, Geschichte, s. 539-544.

${ }^{50}$ Cramer, Das Grosse Pomrische Kirchen-Chronicon, s. 90.

${ }^{51}$ Tamże, s. 92.
} 
kie warstwy społeczne, nie powodując zakłóceń w życiu publicznym. Między rokiem 1523 a 1532 ograniczono sprawowanie kultu katolickiego w większości miast pomorskich. Głównym motorem tego procesu było mieszczaństwo, które gościło u siebie luterańskich kaznodziejów, dawało im schronienie przed władzą, przejmowało ambony i wyganiało bądź zastraszało księży katolickich, tak że sami opuszczali swoje parafie ${ }^{52}$.

W tym pokojowym procesie przyjmowania protestantyzmu niechlubny wyjątek można odnotować w mieście Stralsund, mieszczaństwo bowiem bardzo szybko przyjęło naukę M. Lutra, czemu towarzyszyły gwałtowne zamieszki ${ }^{53}$. Powstały konflikt wyznaniowy miał jednak naturę polityczno-społeczną. Na przełomie XV i XVI wieku doszło do podziału wśród mieszczaństwa, wytworzyła się bowiem elita nielicznych patrycjuszy, do którego wstępu nie miała większość mieszkańców miasta. Ponadto minęły lata świetności hanzy jako sojuszu bogatych miast. Związek zaczął ulegać erozji, co przysporzyło miastom licznych problemów ekonomicznych. Wśród mieszczaństwa szerzyła się fala niezadowolenia skierowana również $\mathrm{w}$ kierunku duchowieństwa katolickiego ze względu na jego niechęć do partycypacji w redukcji obciążenia gospodarczego miasta. Instytucje kościelne mające prawa handlowe starały się konsolidować własny budżet, zasłaniając się przywilejem wolności podatkowej ${ }^{54}$.

W tej sytuacji na początku lat 20. XVI wieku ${ }^{55}$ do Stralsund przybyli pierwsi kaznodzieje luterańscy, którzy zostali przychylnie przyjęci przez niższe warstwy społeczne i średnie mieszczaństwo, wśród którego duchowieństwo diecezjalne i zakonne nie cieszyło się popularnością. Niechęć do kleru nie była jednak uwarunkowana jedynie rolą Kościoła w życiu gospodarczym. Minęły już lata świetności zakonów w mieście, a życie religijne i duszpasterstwo duchowieństwa stralsundzkiego było na niskim poziomie. Krytykowano również braki w edukacji teologicznej duchowieństwa ${ }^{56}$. Próżnię tę wypełnili charyzmatyczni kaznodzieje luterańscy, którzy potrafili swoimi kazaniami przekonać do siebie wiernych. Zaprowadzenie protestantyzmu w Stralsundzie ściśle związane jest $\mathrm{z}$ działalnością Christiana Ketelhota. Urodzony w 1492 roku w Górzycy (Gryficach) był kanonikiem klasztoru norbertanów w Białobokach, gdzie zetknął się z J. Bugenhagenem i przekonał się do tez M. Lutra. Będąc proboszczem fary pw. św. Mikołaja w Słupsku, wygłaszał nauki luterańskie, przez co książę Bogusław X za zgodą biskupa E. Manteuffla w 1522 roku odwołał go z tej funkcji. Obawiając się aresztowania, Ch. Ketelhot opuścił Słupsk i udał się na zachód regionu, w kierunku Meklemburgii. W 1523 roku dotarł do Wołogoszczy, gdzie przebrał się w świeckie ubranie, ponieważ nie chciał być rozpoznany. Przez pewien czas służył szlachcicowi Han-

${ }^{52}$ Biesner, Geschichte, s. 418.

${ }^{53}$ Niemeck, Die Zisterzienserklöster, s. 275-278.

${ }^{54}$ Tamże, s. 276-277.

${ }^{55}$ Andreas Niemeck datuje przyjazd pierwszych kaznodziejów na 1522 rok, aczkolwiek reformacja Stralsundu rozpoczyna się działalnością reformatora $\mathrm{Ch}$. Ketelhota, który dotarł do Stralsund dopiero w 1524 roku. W kronikach nie znalazłem potwierdzenia tego wczesnego datowania A. Niemecka. Tenże, Die Zisterzienserklöster, s. 277.

${ }^{56}$ Tamże. 
sowi Schwerin, po czym udał się do Stralsund. Tam spotkał się z Johannem Kureke, byłym współbratem klasztoru norbertanów w Białobokach. Obaj dobrze się znali, ponieważ wspólnie zetknęli się z J. Bugenhagenem i stali się zwolennikami nauki M. Lutra. Johann Kureke za swoją działalność reformatorską został uwięziony na polecenie biskupa Erazma von Manteuffela ${ }^{57}$. Według zapisek kronikarskich Ch. Ketelhof przybył do miasta hanzy w dniu 23 lub 24 maja 1524 $\mathrm{roku}^{58}$. Nie planował wygłaszać tam Ewangelii, lecz odbyć podróż do Liwonii, gdzie działał jego przyjaciel Andreas Knöpken. Chciał bowiem opuścić Pomorze w obawie przed księciem Jerzym ${ }^{59}$. Zapewne Ch. Ketelhot już w 1523 roku przebywał w Stralsund, był tam bowiem znany. W maju 1524 roku rozpoznano go i poproszono o wygłoszenie homilii. Do Ch. Ketelhofa przychylnie nastawiona była część mieszczaństwa, m.in. późniejszy burmistrz Franz Wessel czy Ludwig Fischer. Christian Ketelhof i A. Kureke wspólnie głosili Ewangelię w duchu reformatorskim. Ich kaznodziejstwo miało przeciwstawny charakter, gdyż A. Kureke atakował Kościół katolicki, podczas gdy homilie Ch. Ketelhofa były bardziej umiarkowane ${ }^{60}$.

Wystąpienia reformatorów powodowały coraz większą polaryzację społeczeństwa miasta. Nauki padły na podatny grunt wśród drobnomieszczaństwa i biednych, podczas gdy elity były podzielone, a duchowieństwo katolickie atakowało reformatorów i starało się wzbudzić wśród wiernych negatywne nastawienie wobec kaznodziejów. Do wybuchu zamieszek doszło w poniedziałek Wielkiego Tygodnia, 10 kwietnia 1525 roku, gdy rozruchy wywołane przez biednych przed kościołem pw. św. Mikołaja doprowadziły do szturmu na kościoły („Stralsunder Kirchensturm"), w wyniku czego zostały zniszczone obrazy, ołtarze i naczynia liturgiczne oraz zdewastowane wnętrza budynków kościołów, kaplic i klasztorów miejskich. Od tego wydarzenia wzrastał wpływ zwolenników M. Lutra, który zwiększył się jeszcze po przyjeździe reformatora Jana Knipstro 1 listopada tego roku do miasta ${ }^{61}$. Mieszczaństwo, które zaczęło popierać nową naukę, wykorzystało sprzyjającą koniunkturę polityczną i wymusiło na rajcach przeprowadzenie nowych wyborów do rady miejskiej. Argumentowano to faktem, że katolicka rada miejska nie mogła reprezentować podzielonego wyznaniowo mieszczaństwa, które w większości było pod wpływem reformacji. W przeciągu kilku tygodni została zwołana nowa rada miejska, w skład której weszli luteranie. Jeszcze w listopa-

${ }^{57} \mathrm{~W}$ areszcie przebywał w 1523/1524 roku, w kronice bowiem zapisano: „bis ins ander Jahr”. Cramer, Das Grosse Pomrische Kirchen-Chronicon, s. 50.

${ }^{58}$ Według D. Cramera 23 maja, wg Groschego 24 maja. Cramer, Das Grosse Pomrische Kirchen-Chronicon, s. 57; tenże, Pommerische Chronica, s. 34; G. Grosch, Nothwendige Verthaidigung der evangelischen Kirche wider die Arnoldische Ketzerhistorie, Frankfurt-Leipzig 1745, s. 221.

${ }^{59}$ „Zu seinem alten Schulbruder“, co oznacza, że znał A. Köpkena z okresu szkolnego (bądź studiów). Cramer, Das Grosse Pomrische Kirchen-Chronicon, s. 57; tenże, Pommerische Chronica, s. 34 .

${ }^{60}$ Cramer, Das Grosse Pomrische Kirchen-Chronicon, s. 57; Grosch, Nothwendige Verthaidigung, s. 221.

${ }^{61}$ Cramer, Das Grosse Pomrische Kirchen-Chronicon, s. 63; tenże, Pommerische Chronica, s. 39. 
dzie tego samego roku przedstawiono nowy porządek kościelny i szkolny. Katolicyzm został szybko wyparty, a duchowieństwo katolickie musiało opuścić miasto. W 1525 roku oficjalnie Stralsund stał się miastem protestanckim ${ }^{62}$.

Proces przejścia mieszczaństwa Stralsund na protestantyzm dotkliwie odczuły opactwa cysterskie w Neuenkamp i Hiddensee. Neuenkamp utrzymywał w Stralsund dwory miejskie - budynki handlowe, w których cystersi utrzymywali towar przeznaczony na handel miejski. Niechęć stralsundczyków skierowana przeciwko Kościołowi odbiła się również na cystersach. Według relacji jednego z kleryków mieszczanie z Stralsund podpalili dom znajdujący się w pobliżu klasztoru Hiddensee, wyśmiali opata i wtargnęli do kaplicy klasztornej. Do podobnych pojedynczych incydentów miało dojść również w Neuenkamp. W sytuacji, gdy mieszczaństwo Stralsund przejęło nową wiarę i wydawało się, że reformacja rozpowszechni się również na wyspie Rugii, książęta Jerzy i Barnim nakazali sporządzić inwentarze majątkowe kościołów i klasztorów oraz skonfiskowali precjoza liturgiczne w celu zachowania ich przed potencjalną grabieżą i zniszczeniem ${ }^{63}$.

Wiosną 1535 roku książęta pomorscy przeprowadzili w asyście reformatora J. Bugenhagena wizytację klasztoru Neuenkamp. W dniu 8 maja 1535 roku pomiędzy opatem Janem Molnerem a książętami pomorskimi podpisano umowę o likwidacji klasztoru. Książę Filip pozwolił zakonnikom pozostać w klasztorze, choć mogli go też opuścić, przy czym obiecał również wsparcie finansowe zakonników w postaci dożywotnich rent lub jednorazowej odprawy. Opat J. Molner miał przekazać klasztor wraz z mieniem oraz zasobami zboża na ręce świeckiego administratora (rentmistrza). Następnie przejął mieszkanie w posiadłości miejskiej klasztoru w Stralsund, a po śmierci opata dwór miejski miał zostać przekazany na własność księstwa. Jednak faktycznie musiał opuścić mieszkanie w Stralsund już w $1538 \mathrm{roku}^{64}$. Opat otrzymywał również rentę, której wysokość z biegiem czasu obniżano. W 1569 roku książę Bogusław XIII wzniósł na ruinach klasztoru pałac, a w 1587 roku powstało obok nowe miasto (Franzburg), istniejące do dzisiaj ${ }^{65}$.

Z punktu widzenia prawnego bardzo interesującą kwestię stanowi pozew cywilny wystosowany przez opata Neuenkamp J. Molnera wraz z opatem klasztoru macierzystego w Altenkamp, von Hülsem przeciwko książętom pomorskim Barnimowi i Filipowi. Używając dzisiejszego języka, pozew można uznać za jeden z pierwszych przypadków skarg konstytucyjnych na tle wyznaniowym w historii Rzeszy. Prawnicy zapewne wystawią opór przeciw takim porównaniom, pozew bowiem był natury cywilnej, a Rzesza nie posiadała konstytucji. Jednak w poniższym przypadku sprawa dotyczy nie tylko kwestii cywilno-majątkowych. Głównym punktem wyjścia pozwu jest bowiem fundamentalna interpretacja systemu prawnego Rzeszy w kwestii stosunku z Kościołem: Otóż pytaniem jest, na ile książęta pomorscy, będący władcą terytorium bezpośrednio przynależącego do Rzeszy, mieli kompetencję do samodzielnego orzeczenia przeprowadzenia refor-

${ }^{62}$ Biesner, Geschichte, s. 418.

${ }^{63}$ Niemeck, Die Zisterzienserklöster, s. 277-279.

${ }^{64}$ F. Fabricius, Urkunden und Copiar des Klosters Neuenkamp im Königlichen Staatsarchiv zu Wetzlar, Szczecin 1891, s. IV.

${ }^{65}$ Tamże, s. I. 
macji, czyli kasaty Kościoła katolickiego. Bezpośredniość, którą miało Pomorze (Reichsunmittelbarkeit), oznaczała, że kwestie regulujące relację między państwem a Kościołem mogły zostać zmienione tylko przez organy Rzeszy i cesarza, a nie przez władców terytorialnych. Inaczej mówiąc, kasata wygłoszona na sejmie trzebiatowskim i przeprowadzona przez książęta pomorskie była postrzegana przez powodów jako nielegalna. Dzisiaj powiedzielibyśmy, iż władca likwidując konkretne wyznanie (lub konkretną instytucję kościelną), złamał konstytucję, wykroczył bowiem poza zakres swoich kompetencji. Notabene, takie dyskusje natury prawnej dotyczące legalności kasat w świetle prawa Rzeszy pojawiały się po dalszych sekularyzacjach nowożytnych, np. po kasacie jezuitów w 1773 roku czy po kasatach józefińskich po 1782 roku.

Taką myślą kierował się adwokat dr Simon Engelhart, reprezentujący opatów, wnosząc skargę do najwyższej instancji sądownictwa Rzeszy. Udokumentował również w oryginałach przywileje, które klasztor uzyskał już od cesarza Zygmunta Luksemburskiego ${ }^{66}$. Miał być to dowód na to, że książęta łamią wolę własnego zwierzchnika, którym jest cesarz. Zachowanym źródłem tego procesu jest odpis złożonego w Sądzie Kameralnym Rzeszy przez adwokata opatów wykazu pliku oryginalnych dokumentów klasztornych od czasu średniowiecza oraz kopiariusza $^{67}$. Kopiariusz wymienia 103 dokumenty od okresu XIII wieku. Autor, Ferdinand Fabricius w wydanym w 1891 roku w Szczecinie odpisie zwraca uwage na to, iż już w 1574 roku książę wołogoski Ernest Ludwik w piśmie do księcia Bogusława XIII twierdził, że nie posiadał żadnego wykazu dokumentów poklasztornych z Neuenkamp, wszystkie bowiem dokumenty zostały zabrane przez ostatniego opata, a nawet starania zmarłego ojca $\mathrm{w}$ celu ich odzyskania w przeszłości nie przyniosły skutku. Zatem już kilkadziesiąt lat po rozpoczęciu procesu, w zasobach archiwum książęcym wołogoskim nie zachowały się żadne akta. Znajdowały się one jednak w zasobach archiwum Sądu Kameralnego, który do rozwiązania Rzeszy w 1806 roku działał w Wetzlar (w okresie przeprowadzenia kasaty w Spirze). W chwili sporządzenia odpisu pod koniec XIX wieku w zasobach archiwum sądowego znaleziono jedynie tylko niewielką część aktów procesowych, zatem z biegiem czasu zaginęła znaczna część dokumentacji.

Po złożeniu skargi w 1535 roku adwokat opata jednocześnie wytoczył w 1536 roku miastu Stralsund odrębny pozew majątkowy z powodu utraty dochodów, które opat uzyskiwał przez działalność młyna należącego do klasztoru, a także przez handel solą i zyskami odsetkowymi z tytułu pożyczania pieniędzy. Obydwa procesy toczyły się równolegle, a posiedzenia sądu odbywały się często $\mathrm{w}$ tym samym terminie. Po trzech latach, gdy opat musiał opuścić mieszkanie w byłym klasztornym dworze miejskim w Stralsund, a jego sytuacja finansowa ze względu na wysokie koszty procesowe pogorszyła się, adwokat S. Engelhart w styczniu 1538 roku złożył w sądzie wniosek o przejęcie przez książęta alimentów rocznych w wysokości 800 guldenów w celu utrzymania opata aż do momentu przywrócenia mu mienia klasztornego. Adwokat książąt oponował, argumentując, iż

\footnotetext{
${ }^{66}$ Tamże, s. III.

${ }^{67}$ Tamże, s. II-III.
} 
obowiązuje umowa regulująca kasatę, zawarta w dniu 8 maja 1535 roku. Umowa ta przewidywała o wiele korzystniejsze warunki finansowe dla książąt niż nowe żądanie opata. Adwokat opata S. Engelhart twierdził jednak, że umowa nie jest prawomocna, gdyż zawierała jedynie pieczęć książęcą, została zatem jednostronnie podyktowana z pozycji siły. Oskarżyciel w dniu 13 maja 1538 roku złożył w sądzie oryginalne dokumenty. Były to wymienione już wyżej kopiariusz i plik zapieczętowanych rękopiśmiennych dokumentów sięgających średniowiecza. Odpis XIX-wieczny szczegółowo opisuje te akta. Protokół sądowy potwierdzający przyjęcie dokumentu sporządzony został w dniu 2 grudnia $1538 \mathrm{roku}^{68}$. Dalszy przebieg procesu jest nieznany ze względu na brak archiwaliów. Wiadomo jednak, że procesy zakończyły się niekorzystnie dla opatów. Z punktu prawnego ciekawe jest wysnucie przypuszczenia, jaką argumentacją posłużył się trybunał, zapewne oddalając pozew, czy było to stwierdzenie, że takie orzeczenie nie podlega kompetencji sądu, czy jednak sąd stwierdził legalność w działaniu książęcym. Kwestie te nie zostały jeszcze podjęte przez historyków prawa.

Również w dependencji Neuenkamp, klasztorze Hiddensee na Rugii na rozkaz księcia pomorskiego w 1525 roku sporządzono inwentarz szat i naczyń liturgicznych, po czym większość sprowadzono na zamek książęcy w Wołogoszczy. Takie zabezpieczenie być może również było uwarunkowane sytuacją polityczną. Rugia należała do duńskiej diecezji Roskilde, która uległa sekularyzacji w 1536 roku. Można wyjść z założenia, że książę pomorski Filip spodziewał się rychłego wprowadzenia reformacji do Danii i obawiał się przejęcia mienia kościelnego przez władców duńskich, do czego jednak nie doszło. W październiku 1536 roku wystosowano umowę o przekazaniu klasztoru wraz z majątkiem na rzecz księcia pomorskiego i tym samym dokonano kasaty. W umowie zapisano, że majątek zostanie zwrócony zakonowi, jeżeli sobór kościelny odeprze reformację i przywróci na Pomorzu wiarę katolicką. O losach zakonników niewiele wiadomo. Najprawdopodobniej większość z nich rozproszyła się po wyspie, część z księży została ewangelickimi pastorami, a część nie opuściła klasztoru. Opat Jerzy Vilter przeprowadził się na dwór klasztorny w Stralsund, w którym spędził resztę życia. Po śmierci został pochowany w kościele pw. św. Mikołaja w Stralsund ${ }^{69}$.

Podobny los spotkał klasztor cystersów w Słupie koło Anklam. Jeszcze w 1520 roku został wybrany nowy opat z nadzieją na przywrócenie świetności życia zakonnego. Książęta pomorscy już w 1532 roku postanowili sekularyzować klasztor, co nastąpiło w 1534 roku. Kompleks poklasztorny został przekształcony na urząd książęcy. Podczas wojny trzydziestoletniej zdewastowano klasztor, w 1648 roku przejęli go Szwedzi, a w 1720 roku Prusacy. Nie zachowały się źródła historyczne przedstawiające postawę zakonników wobec reformacji, dlatego też trudno zrekonstruować tamtejsze dzieje.

\footnotetext{
${ }^{68}$ Tamże, s. I-V.

${ }^{69}$ Niemeck, Die Zisterzienserklöster, s. 277-279.
} 


\section{Podsumowanie}

Na podstawie zachowanych archiwaliów można przyjąć, że idee reformacji zostały szybko przyjęte w wielu wspólnotach zakonnych, przez co kasata zakonów nastąpiła niejako od wewnątrz. Na tym polega fundamentalna różnica między kasatą przeprowadzoną w dobie reformacji, a pruską z 1810 roku. Młodzi klerycy byli przychylnie nastawieni na naukę $M$. Lutra i to oni stali się reformatorami pomorskimi, szerzyli bowiem nowe nauki wśród wiernych. Książęta pomorscy po wstępnej powściągliwości zaczęli wspierać luteranów i sami wypowiedzieli się za nową nauką. Również i w tym przypadku istotnym motywem działania książąt była ich sytuacja finansowa, dlatego J. Bugenhagenowi nie udało się zachować substancji klasztornej w celu wykorzystania jej do stworzenia ewangelickich szkół i seminariów teologicznych. Jednak ogromny wpływ ideologiczny, który został zapoczątkowany w klasztorze norbertanów w Białobokach przez reformatora J. Bugenhagena $\mathrm{i}$ jego sprzymierzeńców, przyczynił się do tego, iż mieszczaństwo podupadających miast hanzy z różnych względów było nastawione w sposób antyklerykalny i otwarcie przywitało reformatorów. Kasata klasztorów pozamiejskich, w tym cysterskich, przeprowadzana była osobiście przez książęta w asyście J. Bugenhagena. Reformatorzy oferowali młodym klerykom przejście na służbę nowego kościoła, a ci w większości ochoczo przyjęli ofertę. Można wyjść z założenia, że przychylne nastawienie do reformacji, a nie zabezpieczenie finansowe było główną przyczyną przejścia młodych kleryków katolickich do nowych struktur wyznania augsburskiego. Tym samym J. Bugenhagen zadbał o stworzenie nowej elity duchowej. Zakonnicy, którzy chcieli zostać w klasztorze, otrzymali dach nad głową i skromne świadczenia finansowe. Pozostali w klasztorach należeli jednak do nielicznych, a dodatkowo do starszego pokolenia, większość bowiem kleryków opuściła zakony. Do wojny 30-letniej budynki poklasztorne zachowały się w dobrym stanie, gdyż były użytkowane. Liczne zawirowania wojenne w XVII i XVIII wieku oraz zmiany w panowaniu politycznym przyczyniły się do tego, że większość klasztorów dzisiaj nie istnieje, a po części z nich pozostały jedynie ruiny. 


\section{BIBLIOGRAFIA}

Biesner Julius Heinrich, Geschichte von Pommern und Rügen. Nebst angehängter Specialgeschichte des Klosters Eldena, Greifswald 1839.

Brück Thomas, Die Greifswalder Schiffahrt im Spätmittelalter und in der frühen Neuzeit (1250 bis 1774), w: Greifswald, red. H. Wernicke, s. 235-252.

Doris Bulach, Die städtischen Beziehungen der vorpommerschen Klöster Eldena, Neuenkamp und Hiddensee, w: Zisterziensische Klosterwirtschaft zwischen Ostsee und Erzgebirge. Studien zu Klöstern in Vorpommern, zu Himmelpfort in Brandenburg und Grünhain in Sachsen, red. W. Schich, (Studien zur Geschichte, Kunst und Kultur der Zisterzienser, t. 19), Berlin 2004, s. 15-178.

Cramer Daniel, Das Grosse Pomrische Kirchen-Chronicon: Das ist Beschreibung Und Außführlicher Bericht, was sich fürnemblich in Religions Sachen, von Enderung der Heydenschafft her, im Land zu Pomren, und zugehörigem Fürstenthumb Rügen, auch Graff- und Herrschafften, bey noch wehrendem Christenthumb..., t. 3, Szczecin 1628.

Cramer Daniel, Pommerische Chronica // Das ist Beschreibung und ausführlicher Bericht / wie anfenglich durch Bischoff Otto von Bamberg / die Pommern aus heidnischer Blindheit zum Christentumb belehret..., Frankfurt am Main 1602.

Delprat Guillaume Henri Marie, Die Bruderschaft des gemeinsamen Lebens. Ein Beitrag zur Geschichte der Kirche, Litteratur und Pädagogik des vierzehnten, fünfzehnten und sechzehnten Jahrhunderts, Leipzig 1840.

Fabricius Ferdinand, Urkunden und Copiar des Klosters Neuenkamp im Königlichen Staatsarchiv zu Wetzlar, Szczecin 1891.

Greifeld Alexander, Die Auswirkungen der mittelalterlichen Ostexpansion in Vorpommern und Rügen unter besonderer Berücksichtigung der Zisterzienserklöster Eldena und Neuenkamp, Diss. phil. (mps), Greifswald 1967.

Grosch Georg, Nothwendige Verthaidigung der evangelischen Kirche wider die Arnoldische Ketzerhistorie, Frankfurt-Leipzig 1745.

Hahn J. Ph. A., Pauli Gotthard Friedrich (red.), Pommersches Archiv der Wissenschaften und des Geschmaks, t. 4, Szczecin, Anklam 1785.

Hoogeweg Hermann, Die Stifter und Klöster der Provinz Pommern, t. 1, Szczecin 1924.

Hoogeweg, Hermann, Die Stifter und Klöster der Provinz Pommern, t. 2, Szczecin 1925.

Kattinger Detlef, Die Stadtentwicklung vom Ende des 13. Jahrhunderts bis 1500, w: Greifswald, red. H. Wernicke, s. 33-60.

Kloer Hans, Das Zisterzienser-Kloster Eldena in Pommern (Kunstwissenschaftliche Studien 1), Berlin 1929.

Leder Hans Günter, Johannes Bugenhagen Pomeranus - Nachgelassene Studien zur Biographie,(Greifswalder theologische Forschungen, t. 15), Greifswald 2008.

Niemeck Andreas, Die Zisterzienserklöster Neuenkamp und Hiddensee im Mittelalter (Veröffentlichungen der Historischen Kommission für Pommern V, 37), Köln u.a. 2002.

Pyl Theodor, Geschichte des Cistertienserklosters Eldena im Zusammenhange mit der Stadt und Universität Greifswald, t. 1, Greifswald 1880-1881.

Schich Winfried (red.), Zisterziensische Klosterwirtschaft zwischen Ostsee und Erzgebirge. Studien zu Klöstern in Vorpommern, zu Himmelpfort in Brandenburg und Grünhain in Sachsen (Studien zur Geschichte, Kunst und Kultur der Zisterzienser, t. 19), Berlin 2004.

Uckeley Alfred, Die letzten Jahre des Klosters Eldena, „Pommersche Jahrbücher“, 7 (1906) s. 27-87.

Wernicke Horst (red.), Greifswald. Geschichte der Stadt, Schwerin 2000. 


\section{DIE AUFHEBUNG DER ZISTERZIENSERABTEIEN IN VORPOMMERN ZUR ZEIT DER REFORMATION}

\section{Zusammenfassung}

Bis zur Reformation war Pommern eine Klosterlandschaft mit blühendem Ordensleben, auch wenn die Verbreitung der christlichen Religion im 12. Jahrhundert relativ spät erfolgte. Aufgrund der Grenzlage Pommerns und der schwachen politischen Stabilität holten die Landesfürsten Ordensgeistliche aus Skandinavien und dem Heiligen Römischen Reich, die Pfarrseelsorge betrieben und somit zur Verbreitung des Christentums in Pommern beitrugen. Im 12. und 13. Jh. wurden mehrere Zisterzienserkonvente gegründet, die ihre Tätigkeit bis zur Reformation prächtig entfalteten und auf das öffentliche sowie wirtschaftspolitische Leben Einfluss nahmen.

Der Einzug der Reformation in Pommern erfolgte sukzessiv und ruhig, abgesehen von der Hansestadt Stralsund, in der nach dem „Stralsunder Kirchensturm“ alle katholischen Geistlichen aus der Stadt gewaltsam vertrieben wurden. Zu den Trägern der Lehre Luthers wurden sehr rasch junge Ordensgeistliche, darunter auch Zisterzienser, die unter dem Einfluss des auf den Universitäten vorherrschenden Humanismus für die „,neue Lehre“ empfänglich wurden. Der Einzug der Reformation in die Ordensgemeinschaften führte zur inneren Auflösung der Konvente, so dass die durch die pommerschen Herzöge 1534 beschlossene Einführung der Reformation in Pommern, in deren Folge das katholische Leben in dieser Region verschwand, eine logische Konsequenz der vorherrschenden Situation unter den Gläubigen war. Der vorliegende Beitrag zeigt den Verlauf der zisterziensischen Klosteraufhebungen in Vorpommern auf. Am exemplarischen Beispiel des Klosters Eldena werden vordergründig Quellen ausgewertet, die aus dem direkten Umfeld des Ordens stammen: Es sind Memoiren des jungen Zisterziensermönches Anton Remmelding, der Zeit- und Augenzeuge der Aufhebung und der vorangehenden Prozesse gewesen war. Sosehr der retrospektiv verfasste Bericht Remmeldings ideologisch gefärbt war, da er ihn zum Zeitpunkt verfasste, als er bereits eine evangelische Pastorenstelle innehatte, sind diese Memoiren eine erkenntnisreiche Quelle. Diese zeigt das zwischenmenschliche Drama der Mönche auf, die sich inmitten einer verhärteten Front von erbitterten Kämpfern für die Bewahrung althergebrachter Traditionen und Anhängern der neuen Lehre befanden.

Schlüsselworte: Reformation in Pommern; Zisterzienser; Klosteraufhebung in Vorpommern; Johannes Bugenhagen; Anton Remmelding; Erasmus von Manteuffel; Eldena; Neuenkamp; Hiddensee; Stralsund; Greifswald; Belbuck; Treptow an der Rega; Cammin; Greifen; Herzogtum Pommern 


\title{
DISSOLUTIONS OF CISTERCIAN ABBEYS IN WESTERN POMERANIA IN THE REFORMATION PERIOD
}

\begin{abstract}
Summary
Until the Reformation, Pomerania was a land of monasteries and rich monastic life, but the Christianization of the region took place exceptionally late, namely in the 12th century. Due to their border-adjacent location and the labile political situation connected with it, the rulers brought monks from Scandinavia and from the depths of the Roman Empire, who, while holding the position of pastors, helped to expand the Christian faith in Pomerania. In the 12th and 13th century Cistercian conventions were established, which had developed dynamically until the Reformation period, influencing public, economic and political life.

The Reformation was carried out gradually and calmly in Pomerania, with the exception of the city of Stralsund belonging to Hanseatic League, from which Catholic clerics were expelled. The young alumni of the convents, including the Cistercian Order, who were open to the 'new teaching' of the reformers quickly became supporters of Luther's teachings under the influence of humanism spreading in the universities. The change in the attitude of the young monks led to an internal rupture of religious orders; therefore, the official conversion the Augsburg Confession by the Dukes of Pomerania in 1534, establishing the departure of Pomerania from Catholicism, was a logical consequence of the actual state among the faithful. The above dissertation presents the course of dissolutions of the Cistercian monasteries in Western Pomerania. The key point of reference for the source documentation are the notes made in the case of Eldena Monastery by one of the eyewitnesses of the events, a young monk Anton Remmelding, and later an Evangelical pastor. Despite the the ideological bias of the chronicler presenting earlier events after the transition to Lutheranism, the records are an interesting source presenting the human dramas of the friars who found themselves on the ideological front line of the division between the ardent defenders of the values passed on for centuries and the radical new teaching.
\end{abstract}

Keywords: Reformation in Pomerania; Cistercians; dissolution of orders in Pomerania; Johannes Bugenhagen; Anton Remmelding; Erasmus von Manteuffel-Arnhausen; Eldena; Neuenkamp; Hiddensee; Stralsund; Greifswald; Białoboki; Trzebiatów; Kamień Pomorski; the House of Griffin; the Duchy of Pomerania 